\title{
SELECTION CRITERIA, YIELD RELATIONSHIP WITH COMPONENT TRAITS AND GROUPING OF TROPICAL JAPONICA, INDICA LINES AND DERIVED HYBRIDS OF RICE (Oryza sativa L.)
}

\author{
Sandeep Kumar Soni ${ }^{*}$, V.K. Yadav, N. Pratap ${ }^{1}$, V.P. Bhadana ${ }^{2}$ and T.Ram ${ }^{2}$ \\ Department of Genetics and Plant Breeding, C.S.A. University of Agriculture and Technology, \\ Kanpur-208 002 (UP) India
}

\begin{abstract}
Forty-five rice lines comprising of thirty derived hybrid lines obtained from ten tropical Japonica, three Indica and two national checks viz. Pusa Basmati 1121 and Sarjoo-52 were evaluated for selection parameters, yield contributing components and genetic divergence. Fifteen quantitative and three qualitative traits were studied from experimentation with randomized block design during Kharif 2011. The phenotypic coefficient of variability was higher than genotypic coefficient of variability for all of the traits. The highest estimates of broad sense heritability coupled with genetic advance in per cent of mean was recorded for spikelets per panicle, plant height followed by L:B ratio, spikelets per panicle, grains per panicle, biological yield per plant, flag leaf area, days to $50 \%$ flowering, plant height which might be due to the additive nature of gene action. Such results indicated that these traits will be reliable for the effective selection. Highly positive and significant correlation was observed at both phenotypic and genotypic level between grain yield per plant and biological yield per plant, followed by panicle bearing tillers per plant, spikelet fertility, panicle length, 1000grain weight, grains per panicle, panicle weight, flag leaf length, spikelet per panicle, flag leaf area, kernel length, flag leaf width, days to 50\% flowering, and harvest index. This relationship reflected that grain yield and aforesaid economic traits can be increased simultaneously in breeding programme to develop high yielding Indica as well as Tropical Japonica rice varieties. Whole genotypes grouped in 8 non-overlapping clusters exhibited maximum genetic diversity between clusters III i.e., TJ-
\end{abstract}

\footnotetext{
* Corresponding author email: sandeepsoni71187@gmail.com

${ }^{1}$ Deptt. of Genetics \& Plant Breeding, N.D. Univ. of Agri. \& Tech. Kumargang, Faizabad-224 229 (UP) India

${ }^{2}$ Deptt. of Genetics \& Plant Breeding, Directorate of Rice Research, Rajendranagar, Hyderabad- 500030 (AP) India
}

Received: 23.09.2012 
$64897 \times$ NDR-359, TJ-64897 $\times$ CSR36, TJ-64897 $\times$ PB-1 and VIII i.e., TJ-11010 × NDR359, TJ-11010 × PB-1, TJ-16081 × NDR-359, TJ-16081 $\times$ PB-1. These clusters also stand for early days to flowering, short slender, second highest harvest index and panicle bearing tillers per plant, spikelets per panicle, grains per panicle, spikelet fertility, 1000grain weight, long bold slender, biological yield per plant, and grain yield per plant. These genotypes showing higher mean performance for aforesaid traits can be exploited for enhancing hybrid vigour of desired New Plant Type with higher number of panicle bearing tillers per plant, spikelet per panicle and grains per spike in Indica as well as Tropical Japonica rice varieties for achieving higher yield.

Keywords: Clustering pattern, Correlations, Genetic diversity, Indica, Japonica, New Plant Type, Path analysis and Selection parameters.

\section{INTRODUCTION}

Rice as lifeline for a large segment of the world's population, more than $91 \%$ of world's rice is produced in Asia and provides $20 \%$ of the per capita energy and $13 \%$ of the per capita protein worldwide. However, in Asia rice contributes about $35 \%$ of the energy and $28 \%$ of the protein. In India it plays an integral role for 65 per cent population, food security, income generation, employments and foreign currencies gains for the nation. India has the largest area, about $4.5 \times 10^{7}$ ha, under rice in the world and produced $9.5 \times 10^{9}$ tone in year 2010-11. In accordance with current population growth, rice requirement by 2025 is estimated to be around $1.3 \times$ $10^{10}$ tone (Anonymous 2010). Hence it is very crucial to develop high yielding varieties. It is cultivated on foot hills of the Himalaya in the North Western parts of Indian sub-continent comprising the states of Haryana, Punjab, Uttaranchal, Uttar Pradesh, Himachal Pradesh and Delhi. Current Indica rice varieties have higher yield potential of $100 \mathrm{t} \mathrm{ha}^{-1}$ with harvest index of 0.4-0.5 under tropical conditions.

The hybrid vigour between Indica and Japonica inter-subspecies can be used to improve the yield of Indica and Japonica hybrids by introducing parts of the Indica genomic segments into the Japonica background or vice versa, after several generations of backcrossing. For developing New Plant Type with increased vigour, Indica and Japonica materials are an effective source of breeding for the many pleasing and desirable traits such as less and productive tillers, canopy structure, increased biomass production, reduced carbon assimilation, increased harvest index, increased sink-source and spikelet fertility.

Crop improvements depend upon the magnitude of genetic variability present in the base population. The expected improvement in yield components primarily depends on the nature and magnitude of heritable total variation. Selection based on a single character may not always be effective while it is impractical for a researcher to consider a large number of component characters simultaneously in a particular selection procedure. Correlation analysis between yield and its components provides 
useful information for right choice of characters in the selection programme. Path coefficient analysis provides an effective tool for partitioning the correlation coefficient in to direct and indirect effects of yield attributes on yield, with their cause and effect relationship.

The varieties originated from widely distinct localities or geographical areas were usually presumed to be diverse and were utilized in hybridization programmes because earlier workers regarded this geographical isolation as reasonable index of genetic diversity. However, several workers have found the lack of parallelism between geographical distribution and genetic diversity in different crop species and have also reported that genetic drift and selection in different environments could cause greater diversity than geographic distances. (Murty and Arunachalam, 1966; Bhanumathi et al., 2010; Manikya and Reddy, 2011). For improving genetic diversity of best suited germplasm across the location, it is very important to know the extent of existing genetic diversity. Genetic diversity is the heritable difference among germplasm, is crucial at an optimum level within a population to facilitate and sustain an effective, continuous breeding programme. Exotic introduced materials have specific genetic background and also may play a greater role to enhance heterosis.

\section{MATERIALS AND METHODS}

The reported experiment included forty-five rice lines comprising of ten Tropical Japonica as lines and three Indica as testers and their thirty crosses along with two checks viz. Pusa Basmati 1121 and Sarjoo-52. The genotypes were evaluated in Randomized Block Design with three replications during kharif 2011. The crosses were made during kharif 2010 at Crop Research Farm, Nawabganj of C.S. Azad University of agriculture and Technology, Kanpur, situated between $27.24^{\circ} \mathrm{N}$ latitude, $77.5^{\circ} \mathrm{E}$ longitudes and at an altitude of 178 meters above the msl. in the gangetic plain of central Uttar Pradesh. The climate of district Kanpur is semiarid with hot summer and cold winter. Nearly 80 percent of total rainfall occurs during the monsoon (only up to September) with a few showers in the winter. The site of experiment was salt affected clay loam (natrustalf) soil having $\mathrm{pH}=10.5$, EC $=2.03$ and low in organic carbon, nitrogen and phosphorus.

Observations were recorded on ten competitive plants randomly selected in each replications for fifteen quantitative and three qualitative traits viz., days to $50 \%$ flowering, plant height $(\mathrm{cm})$, panicle bearing tillers per plant, flag leaf length $(\mathrm{cm})$, flag leaf width $(\mathrm{cm})$, flag leaf area $\left(\mathrm{cm}^{2}\right)$, panicle length $(\mathrm{cm})$, panicle weight $(\mathrm{g})$, spikelets per panicle, grains per panicle, spikelet fertility (\%), 1000-grains weight (g), kernel length (mm), kernel breadth (mm), L:B ratio, biological yield per plant (g), harvest index (\%) and grain yield plant (g). Each genotype was accommodated in three-row of $5 \mathrm{~m}$ length following row to row and plant to plant spacing of $20 \times 15 \mathrm{~cm}$, respectively. The recommended dose of fertilizers N: P: K @ 120:60:60 kg ha ${ }^{-1}$, cultural packages and practices were followed to raise a good healthy crop. 
Standard statistical techniques such as analysis of variance (Panse and Sukhatme, 1967), genotypic and phenotypic coefficients of variation (Burton and de Vane, 1953), estimate of broad sense heritability $\left(\mathrm{h}^{2}{ }_{\mathrm{b}}\right)$ (Hanson et al., 1956), genetic advance as percent of the mean (Johnson et al., 1955), phenotypic and genotypic correlation coefficient (Searle 1961), path analysis (Dewey and Lu, 1959) and standard statistical techniques such as Non-hierarchical Euclidean cluster analysis (Beale, 1969; Spark, 1973) were applied for assessing variability and genetic divergence present in the germplasm (using MASTA-C software). Grouping and arrangement of genotypes were done by Tocher's method (Rao, 1952).

\section{RESULTS AND DISCUSSION}

\section{Genetic variability parameters}

The analysis of variance revealed presence of highly significant differences among all the genotypes for eighteen characters and indicated considerable amount of variability in the genotypes. Significant variability due to treatment for all the characters (Table 1) was also confirmed by Jayasudha and Sharma (2010). Phenotypic coefficient of variability (PCV) was higher than genotypic coefficient of variability (GCV) (Table 2). A perusal of coefficient of variability indicates that PCV and GCV were quite high for flag leaf area (47.79 \& 47.06), panicle bearing tillers per plant (46.94 \& 44.65), grains per panicle (45.92 \& 45.14), grain yield per plant (44.32 \& 43.07), biological yield per plant (40.73 \& 39.22), spikelets per panicle (38.88 \& 38.33), panicle weight (38.71 \& 38.22), flag leaf width (28.86 \& 28.36), and flag leaf length (25.16 \& 24.26). Moderate PCV and GCV were recorded in panicle length (19.1 \& 18.35), L:B ratio (17.18 \& 16.56), 1000-grain weight (16.05 \& 15.89), kernel breadth (14.82 \& 14.21), days to 50\% flowering (14.82 \& 14.14), spikelet fertility (12.09 \& 8.94), plant height (11.68 \& 11.29) and kernel length (10.95 \& 10.69) by Seyoum et al., 2012, Yadav et al., 2011, Manikaya and Reddy, 2011 and Barber et al., 2009. The highest estimates of broad sense heritability coupled with genetic advance in per cent of mean was recorded for spikelets per panicle (96.60 \&149.86), plant height (98.9\% \& 65.13\%) followed by L:B ratio (99.99 \& 39.30), spikelets per panicle (97.20 \& 32.39), grains per panicle (96.60 \& 141.11), biological yield per plant (92.70 \& 42.47), flag leaf area (97.00 \& 40.47), days to $50 \%$ flowering ( $91.10 \& 26.75$ ), and plant height (93.40 \& 25.04). Due to the additive nature of gene action these traits will be reliable for the effective selection. High heritability coupled with moderate genetic advance for grain yield per plant (94.40 \& 15.22) and flag leaf length (93.00 \& 13.62) indicated preponderance of non-additive gene action, hence selection cannot be rewarded which was also agreed with by Seyoum et al., 2012; Yadav et al., 2011 and Suman et al., 2005. The most preferable genotypes having high variability, heritability and genetic advance for characters other than grain yield per plant can also be used as donor parents in hybridization programme to improve desirable characters for which they showed high value of heritability and genetic advance. 


\section{Relationship analysis}

The genotypic correlation coefficient was higher in magnitude than the corresponding phenotypic correlation coefficient in general for most of the characters (Table 3). This is possibly due to the linkage or modifying effect of the gene and environment in genetic association between characters (Swain and Reddy 2006). There were strong positive and significant correlation at both phenotypic and genotypic level, between grain yield per plant and biological yield per plant (0.931 \& $0.884)$ followed by panicle bearing tillers per plant $(0.823 \& 0.593)$, spikelet fertility (0.823 \& 0.593), panicle length (0.809 \& 0.752), 1000-grain weight (0.738 \& 0.710 ), grains per panicle ( $0.699 \& 0.666)$, panicle weight $(0.683 \& 0.660)$, flag leaf length (0.678 \& 0.625), spikelet per panicle (0.633 \& 0.604$)$, flag leaf area $(0.628 \&$ $0.599)$, kernel length (0.579 \& 0.549$)$, flag leaf width (0.516 \& 0.499$)$, days to $50 \%$ flowering (0.385 \& 0.351), and harvest index (0.368 \& 0.366). This relationship reflected that grain yield and aforesaid traits can be improved simultaneously (Jaisudha and Sharma, 2010; Manikaya and Reddy, 2011 and Seyoum et al., 2012). Besides, biological yield was positively and highly significantly correlated with panicle bearing tillers per plant (0.881 \& 0.821$)$, grains per panicle (0.794 \& 0.756$)$, spikelet fertility $(0.863 \& 0.620)$ and panicle length $(0.828 \& 0.771)$ and 1000 -grain weight $(0.764 \& 0.730)$. This indicates that vigorous plant population may enhance economic yield. 1000-grain weight was significantly and positively associated with spikelet fertility and panicle length and other yield contributing traits. A highly significant and positive correlation was noted between grains per panicle and panicle length (0.679 \& 0.639), panicle bearing tillers per plant (0.597 \& 570) and panicle weight $(0.843 \& 0.816)$. Panicle weight showed highly significant and positive association with panicle per plant (0.528 \& 0.501) and panicle length (0.772 \& 0.736). Such type of results were reported by Petchiammal and Khan, 2007. This association reflected that above character can be considered as new plant type for enhancing the economic yield.

\section{Path coefficient analysis}

The highest direct effect of grains per panicle (1.208 \& 0.235) was noted over grain yield per plant, followed by flag leaf width (1.197 \& 0.477$)$, biological yield per plant (1.132 \& -0.340), harvest index (0.854 \& 0.725), kernel breadth (0.825 \& $0.330)$, flag leaf length $(0.818 \& 0.373)$ on grain yield via panicle weight $(1.018 \&$ 0.192), spikelets per panicle (1.195 \& 0.230), spikelet fertility (1.013 \& 0.162), biological yield per plant (0.959 \& 0.178), 1000-grain weight (0.852 \& 0.160), panicle length $(0.820 \& 0.150)$, flag leaf area $(0.787 \& 0.150)$, flag leaf length $(0.724$ $\& 0.135)$, flag leaf width $(0.723 \& 0.137)$ and panicle bearing tillers per plant $(0.721$ $\&$ 0.134) (Table 4). Almost similar relationships were also reported by Borbora et al., 2005; Veni and Rani, 2007; and Kisore et al., 2007. Therefore, these traits can be used for selection criteria in breeding programme to develop high yielding new plant type rice varieties. 


\section{Clustering pattern and genetic divergence analysis}

Non-hierarchical Euclidean cluster analysis grouped the forty-five aforesaid genotypes, into 8 non-overlapping clusters (Table 5 and 6). Cluster II had the maximum 13 genotypes, followed by cluster VIII, I, and cluster III, IV, V, VI which had same number of 4 genotypes. Cluster VII comprised of 3 genotypes which reflected narrow genetic diversity (Dushyantha and Kantti 2010).

Maximum inter-cluster diversity was observed between III \& VIII, followed by cluster III \& IV, III \& VII, II \& VIII, III \& VI, II \& IV, IV \& V, I \& VIII and I \& IV. Similar inter-cluster distances were reported by Vaithiyalingan et al., 2007. The genotypes grouped in cluster I consisted of eleven genotypes, only three genotypes i.e. TJ-25966 × NDR-359, TJ-25966 × CSR36, TJ-25966 × PB-1 showed short bold grain and harvest index. It is big information that genotype TJ-64897 $\times$ NDR-359, TJ-64897 × CSR36, TJ-64897 × PB-1 from cluster III and genotype TJ-11010 $\times$ NDR359, TJ-11010 × PB-1, TJ-16081 × NDR-359, TJ-16081 × PB-1 from cluster VIII expressed maximum genetic diversity and also stands for early days to flowering, short slender, second highest harvest index and panicle bearing tillers per plant, spikelets per panicle, grains per panicle, spikelet fertility, 1000-grain weight, biological yield per plant, grain yield per plant. Chandra et al., 2007 also observed similar results in their study. Therefore, it is suggested that any superior genotype of cluster III may be crossed with any superior genotypes of cluster VII to produce desirable recombinants with more suitable traits for higher yield.

Maximum genetic divergence within the cluster was estimated for cluster $\mathrm{V}$ (3.058) followed by cluster II (2.205), VII (1.995), I (1.892), VII (1.378) and VI (1.288) while cluster IV (1.140) showed minimum intra cluster distance. Almost similar inter-cluster distance was estimated by Suman et al., 2005 in rice. The maximum intra cluster value indicated maximum divergence among various genotypes within the cluster whereas; minimum value reflected minimum diversity among the genotypes within the respective cluster.

Based on cluster mean performance (Table-7), cluster VII showed the highest cluster mean for productive tillers per plant (17.73), flag leaf length (35.91), panicle length (31.23), grains per panicle (245.04), 1000-grain weight (32.54), biological yield per plant (85.02), grain yield per plant (28.24). Gahalain et al., 2006 reported similar type of cluster mean in rice.. From this cluster, the genotypes TJ-11010 $\times$ NDR359, TJ-11010 × PB-1, TJ-16081 × NDR-359, TJ-16081 × PB-1 expressed superiority over the checks for aforesaid respective characters. Cluster IV showed maximum mean performance for genotypes TJ-10365 $\times$ NDR-359 and TJ-10365 $\times$ PB-1 for flag leaf width (2.87), flag leaf area (71.97) and spikelet per panicle (284.33). Cluster VII showed third highest mean performance for days to $50 \%$ flowering (87.78), panicle bearing tillers per plant (15.11), panicle length (30.10), spikelet per panicle (275.22), grains per panicle (238.00) and 1000-grain weight (31.00). The highest mean performance for panicle weight (4.16), kernel breadth 
(3.25) were recorded in the two most superior genotypes TJ-25892 $\times$ NDR359 and TJ-25892 $\times$ PB-1 of cluster Vll. Earliness (87.78 days) and desirable medium plant height (116.00) of the above mentioned genotypes can be taken under consideration in crossing program. On the basis of eight genetically diverse clusters, superior genotypes listed in table 8 from the different clusters were selected. Interacting from different clusters and diverse genotypes would lead greater opportunity for crossing over which release latent genetic variability by breaking linkage drag and progenies derived from cross are expected to show broad spectrum of genetic variability providing a greater scope for screening transgressive segregants as new plant type for sustaining yield of existing varieties.

\section{CONCLUSIONS}

The study of fifteen quantitative and three qualitative traits ranging for trait to trait among the genotype, indicated that selection can be practiced for background selection to sort-out superior parent with higher spikelets per panicle, grains per panicle, and panicle bearing tillers per plant due to the additive nature of gene action. The direct yield contributing characters showing strong positive association with grain yield reflected that these characters can be enhanced simultaneously. Similarly genotypes falling under cluster III and VIII having high mean performance for respective character can be used for getting better combinations with desirable character in Indica as well as in Japonica rice varieties for foreground selection to achieve higher yield with desirable new plant type.

\section{ACKNOWLEDGEMENT}

The authors would like to thank Dr. T. Ram (Principal Scientist), Department of Genetics and Plant Breeding, Crop improvement Section and Dr. V.P. Bhadana (Principal Scientist), Department of Genetics and Plant Breeding, Hybrid Rice Section, Directorate of Rice Research, Rajendranagar, Hyderabad (AP) India, for providing the materials, and Dr. V.K. Yadav (Rice Breeder), Department of Genetics and Plant Breeding, CSAUA\&T, Kanpur (UP) India for conducting the field trial timely, valuable suggestions and completion of this manuscript.

\section{REFERENCES}

Anonymous 2010. FAO. statistical data base on agriculture, http:// apps. FAO org

Babar, M., Khan, A. A., Arif, A., Zafar, Y. and Arif, M. 2009. Path analysis of some leaf and panicle traits affecting grain yield in double haploid lines of rice (Oryza sativa $\mathrm{L}$ ). Journal of Agricultural Research, 45 (4): 245-252

Beale, E. M. L. 1969. Euclidean cluster analysis. A paper contributed to $37^{\text {th }}$ season of the International statistical Institute

Banumathi, S.; Thiyagarajan, K. and vaidyanathan, P. 2003. Study on magnitude of heterosis of rice hybrids for yield and its components. Crop Research, 25 (2): 287-293 
Borbora, T. K., Hazarika, G. N. and Medhi, A. K. 2005. Correlation and path analysis for panicle characters in rice. Crop Research, 30 (2): 215-222

Burton, G. W. and de Vane, E. W. 1953. Estimating heritability in tall fescue (Fistuea arundincea) from replicated clonal material. Agronomy Journal, 45: 178-181

Chandra, B. S., Reddy, T. D. and Ansari, N. A. 2007. Genetic divergence in rice (Oryza sativa L.) Research on Crops, 8 (3): 600-603

Dewey, D. R. and Lu, K. H. 1959. A correlation and path analysis of components of crested wheat grass seed production. Agronomy Journal, 57: 515-518

Dushyantha, K. B. M. and Kantti, A. 2010. Genetic divergence in rice accessions of hill zone of Karnataka. Electronic Journal of Plant Breeding, 1 (5): 1329-1331

Gahalain, S.S. 2006. Genetic divergence in rice (Oryza sativa L.) genotypes grown in Kumaun, Himalaya. Indian Journal of Genetics, 66 (1): 37-38

Hanson, G. H., Robinson, H. F. and Comstock, R. E. 1956. Biometrical studies of yield in screening populations of Korean Lesoedeza. Agronomy Journal, 48: 268-272

Jayasudha, S. and Sharma, D. 2010. Genetic parameters of variability, correlation and pathcoefficient for grain yield and physiological traits in rice (Oryza sativa L.) under shallow lowland situation. Electronic Journal of Plant Breeding, 1 (5): 1332-1338

Johnson, H. W., Robinson, H. F. and Comstock, R. E. 1955. Estimates of genetic and environmental variability in Soybean. Agronomy Journal, 47: 314-318

Kishore, N. S., Ansari, N. A., Babu, V. R., Rani, N. S., Rao, L. V. and Subba, R. 2007. Correlation and path analysis in aromatic and non-aromatic rice genotypes. Agricultural Science Digest, 27: Issue 2

Manikya, M. and Reddy, T. D. 2011. Studies on genetic divergence in medium duration elite rice genotypes (Oryza sativa L.). Journal of Research ANGRAU, 39(3): 26-31

Murty, B. R. and Arunachalam, V. 1966. The nature of genetic divergence in relation to breeding system in crop plants. Indian Journal of Genetics, 26(A): 188-198

Panse, V. G. and Shukhatme, P. V. 1967. Statistical Methods for Agricultural Workers. $2^{\text {nd }}$ Edn. ICAR, New Delhi, pp. 152-157

Petchiammal, K. I. and Kumar, C. R. A. 2007. Association analysis for yield and related traits in rice (Oryza sativa L.). International Journal of Plant Sciences, 2 (2): 97-100

Rao, C. R. 1952. Advanced statistical method in biometrical research. Willey and Sons Newyark

Searle, S. R. 1961. Phenotypic, genotypic and environmental correlations. Biometrics, 17: 474-480

Soyoum, M., Alamerew, S. and Bantte, K. 2012. Genetic variability, Heritability, correlation and path analysis for yield and yield related traits in upland rice (Oryza sativa L.). Plant archives, 7 (1): 13-22

Spark, D. N. 1973. Euclidean cluster analysis. Algorithm A. 58. Applied Statistics, 22: 126130

Suman, A., Sankar, V. G., Rao, L. V. S. and Sreedhar, N. 2005. Variability, heritability and genetic advance in rice. Crop Research, 30 (2): 211-214 
Swain, B. and Reddy, J. N. 2006. Correlation and path analysis of yield and its components in rainfed lowland rice genotypes under normal and delayed planting conditions. Oryza, 43(1): 58-61

Vaithiyalingan, M. 2007. Genetic divergence in rice (Oryza sativa L). Journal of Ecobiology, 17 (4): 393-395

Veni, B. K. and Rani, N. S. 2007. Association and path analysis studies for yield and yield components in rice. Journal of Research ANGRAU, 35 (1): 114-118 Yadav, S. K., Pandeey, P., Kumar, B. and Suresh, B. G. 2011. Genetic Architecture, Interrelationship and Selection criteria for yield Improvement in rice (Oryza sativa L). Pakistan Journal of Biological Science, 14(9): 540-545 
Table 1: Estimates of variance for 18 characters in Indica and Tropical Japonica rice lines and their hybrids

\begin{tabular}{|c|c|c|c|c|c|c|}
\hline \multirow[b]{2}{*}{ Sl. No. } & \multirow[b]{2}{*}{ Characters } & \multicolumn{5}{|c|}{ Sources of variation } \\
\hline & & $\begin{array}{l}\text { Replication } \\
\text { (2) }\end{array}$ & $\begin{array}{l}\text { Treatment } \\
\text { (44) }\end{array}$ & $\begin{array}{c}\text { Error } \\
(\mathbf{8 8})\end{array}$ & CV\% & CD \\
\hline 1. & Days to $50 \%$ flowering & 1.50 & $573.36 * *$ & 18.10 & 4.42 & 6.89 \\
\hline 2. & Plant height $(\mathrm{cm})$ & 42.93 & $485.82 * *$ & 11.22 & 3.00 & 5.42 \\
\hline 3. & $\begin{array}{l}\text { Panicle bearing } \\
\text { tillers/plant }\end{array}$ & 2.61 & $73.62 * *$ & 2.49 & 14.48 & 2.56 \\
\hline 4. & Flag leaf length & 2.16 & $144.59 * *$ & 3.56 & 6.67 & 3.06 \\
\hline 5. & Flag leaf Breadth & 0.03 & $0.89 * *$ & 0.01 & 5.36 & 0.16 \\
\hline 6. & Flag leaf area & 3.41 & $1206.68 * *$ & 12.45 & 8.32 & 5.72 \\
\hline 7. & Panicle length (cm) & 1.04 & $70.18^{* *}$ & 1.88 & 5.28 & 2.23 \\
\hline 8. & Panicle weight (g) & 0.02 & $3.10^{* *}$ & 0.02 & 6.15 & 0.26 \\
\hline 9. & Spikelets/panicle & 413.75 & $16496.41^{* *}$ & 158.16 & 6.53 & 20.38 \\
\hline 10. & Grains/spike & 178.37 & $14739.39 * *$ & 169.98 & 8.44 & 21.15 \\
\hline 11. & Spikelet fertility (\%) & 17.59 & $187.43^{* *}$ & 40.54 & 8.13 & 10.31 \\
\hline 12. & 1000- grain weight (g) & 1.96 & $56.87 * *$ & 0.39 & 2.29 & 1.01 \\
\hline 13. & Kernel length & 0.01 & $1.42 * *$ & 0.02 & 2.34 & 0.24 \\
\hline 14. & Kernel breadth & 0.03 & $0.35^{* *}$ & 0.01 & 4.22 & 0.16 \\
\hline 15. & $\mathrm{~L}: \mathrm{B}$ ratio & 0.02 & $0.62 * *$ & 0.01 & 4.57 & 0.19 \\
\hline 16. & Biological yield/plant (g) & 138.51 & $1410.99 * *$ & 35.88 & 10.97 & 9.72 \\
\hline 17. & Harvest index & 124.69 & $106.30 * *$ & 21.90 & 14.37 & 7.59 \\
\hline 18. & Grain yield/plant (g) & 2.71 & $176.87 * *$ & 3.41 & 10.46 & 2.98 \\
\hline
\end{tabular}

*,** Significant at $5 \%$ and $1 \%$ probability levels, respectively 
TROPICAL JAPONICA, INDICA LINES AND DERIVED HYBRIDS OF RICE

Table 2: Estimates of general mean, variability parameters for 18 characters in Indica and Tropical Japonica rice lines and their hybrids

\begin{tabular}{|c|c|c|c|c|c|c|c|c|}
\hline \multirow{2}{*}{ Characters } & \multicolumn{2}{|c|}{ Range } & \multirow{2}{*}{$\begin{array}{l}\text { G. mean } \\
\pm S E(m)\end{array}$} & \multicolumn{3}{|c|}{$\begin{array}{c}\text { Coefficient of variation } \\
(\%)\end{array}$} & \multirow{2}{*}{$\begin{array}{l}\mathbf{h}^{2} \mathbf{b} \\
(\%)\end{array}$} & \multirow{2}{*}{$\begin{array}{l}G \text { a } \\
(\%)\end{array}$} \\
\hline & Minimum & Maximum & & PCV & GCV & ECV & & \\
\hline $\begin{array}{l}\text { Days to } 50 \% \\
\text { flowering }\end{array}$ & 66.25 & 114.00 & $\begin{array}{c}96.19 \pm \\
3.47\end{array}$ & 14.82 & 14.14 & 0.68 & 91.10 & 26.75 \\
\hline Plant height (cm) & 94.00 & 143.33 & $\begin{array}{c}111.41 \pm \\
2.73\end{array}$ & 11.68 & 11.29 & 0.39 & 93.40 & 25.04 \\
\hline $\begin{array}{l}\text { Panicle bearing } \\
\text { tillers/plant }\end{array}$ & 4.65 & 22.67 & $\begin{array}{c}10.90 \pm \\
1.29\end{array}$ & 46.94 & 44.65 & 2.29 & 90.50 & 9.54 \\
\hline Flag leaf length & 17.15 & 41.70 & $\begin{array}{c}28.26 \pm \\
1.54\end{array}$ & 25.16 & 24.26 & 0.9 & 93.00 & 13.62 \\
\hline Flag leaf Breadth & 0.84 & 2.92 & $\begin{array}{c}1.91 \pm \\
0.08\end{array}$ & 28.86 & 28.36 & 0.5 & 96.00 & 1.10 \\
\hline Flag leaf area & 11.06 & 86.56 & $\begin{array}{c}42.39 \pm \\
2.88\end{array}$ & 47.79 & 47.06 & 0.73 & 97.00 & 40.47 \\
\hline Panicle length (cm) & 18.57 & 34.23 & $\begin{array}{c}25.99 \pm \\
0.11\end{array}$ & 19.10 & 18.35 & 0.75 & 92.30 & 9.44 \\
\hline Panicle weight (g) & 1.35 & 4.37 & $\begin{array}{c}2.64 \pm \\
0.13\end{array}$ & 38.71 & 38.22 & 0.49 & 97.50 & 2.06 \\
\hline Spikelets/panicle & 90.67 & 328.67 & $\begin{array}{l}192.55 \pm \\
10.26\end{array}$ & 38.88 & 38.33 & 0.55 & 97.20 & 149.86 \\
\hline Grains/spike & 65.11 & 292.67 & $\begin{array}{c}154.38 \pm \\
10.64\end{array}$ & 45.92 & 45.14 & 0.78 & 96.60 & 141.11 \\
\hline Spikelet fertility (\%) & 64.97 & 89.09 & $\begin{array}{c}78.25 \pm \\
5.19\end{array}$ & 12.09 & 8.94 & 3.15 & 54.70 & 10.66 \\
\hline 1000- grain weight (g) & 18.29 & 34.38 & $\begin{array}{c}27.30 \pm \\
0.51\end{array}$ & 16.05 & 15.89 & 0.16 & 98.0 & 8.85 \\
\hline Kernel length & 4.77 & 7.44 & $\begin{array}{c}6.39 \pm \\
0.12\end{array}$ & 10.95 & 10.69 & 0.26 & 95.40 & 1.38 \\
\hline Kernel breadth & 1.71 & 3.56 & $\begin{array}{c}2.38 \pm \\
0.08\end{array}$ & 14.82 & 14.21 & 0.61 & 91.90 & 0.67 \\
\hline $\mathrm{L}: \mathrm{B}$ ratio & 1.93 & 3.97 & $\begin{array}{c}2.73 \pm \\
0.10\end{array}$ & 17.18 & 16.56 & 0.62 & 92.90 & 0.90 \\
\hline $\begin{array}{l}\text { Biological yield/plant } \\
\text { (g) }\end{array}$ & 18.27 & 110.73 & $\begin{array}{c}54.59 \pm \\
4.89\end{array}$ & 40.73 & 39.22 & 1.51 & 92.70 & 42.47 \\
\hline Harvest index & 20.86 & 50.28 & $\begin{array}{c}32.56 \pm \\
3.82\end{array}$ & 21.72 & 16.29 & 5.43 & 56.20 & 8.19 \\
\hline Grain yield/plant (g) & 5.59 & 34.98 & $\begin{array}{c}17.65 \pm \\
1.50\end{array}$ & 44.32 & 43.07 & 1.25 & 94.40 & 15.22 \\
\hline
\end{tabular}


Table 3: Genotypic and Phenotypic correlation coefficients for 18 characters in Indica and Tropical Japonica rice lines and their hybrids

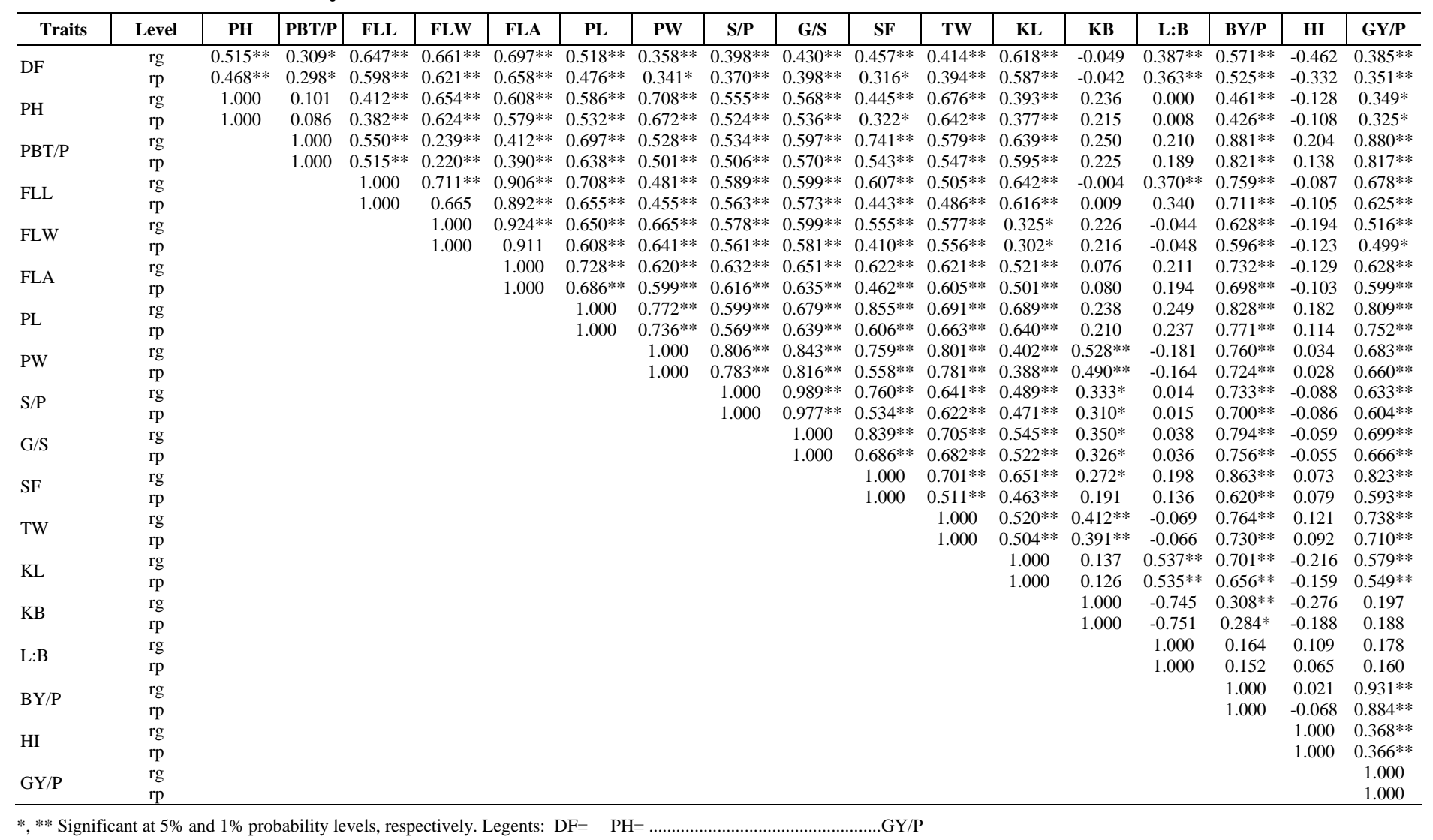


Table 4: Genotypic and Phenotypic path of 18 traits on grain yield in Indica and Tropical Japonica rice lines and their hybrids

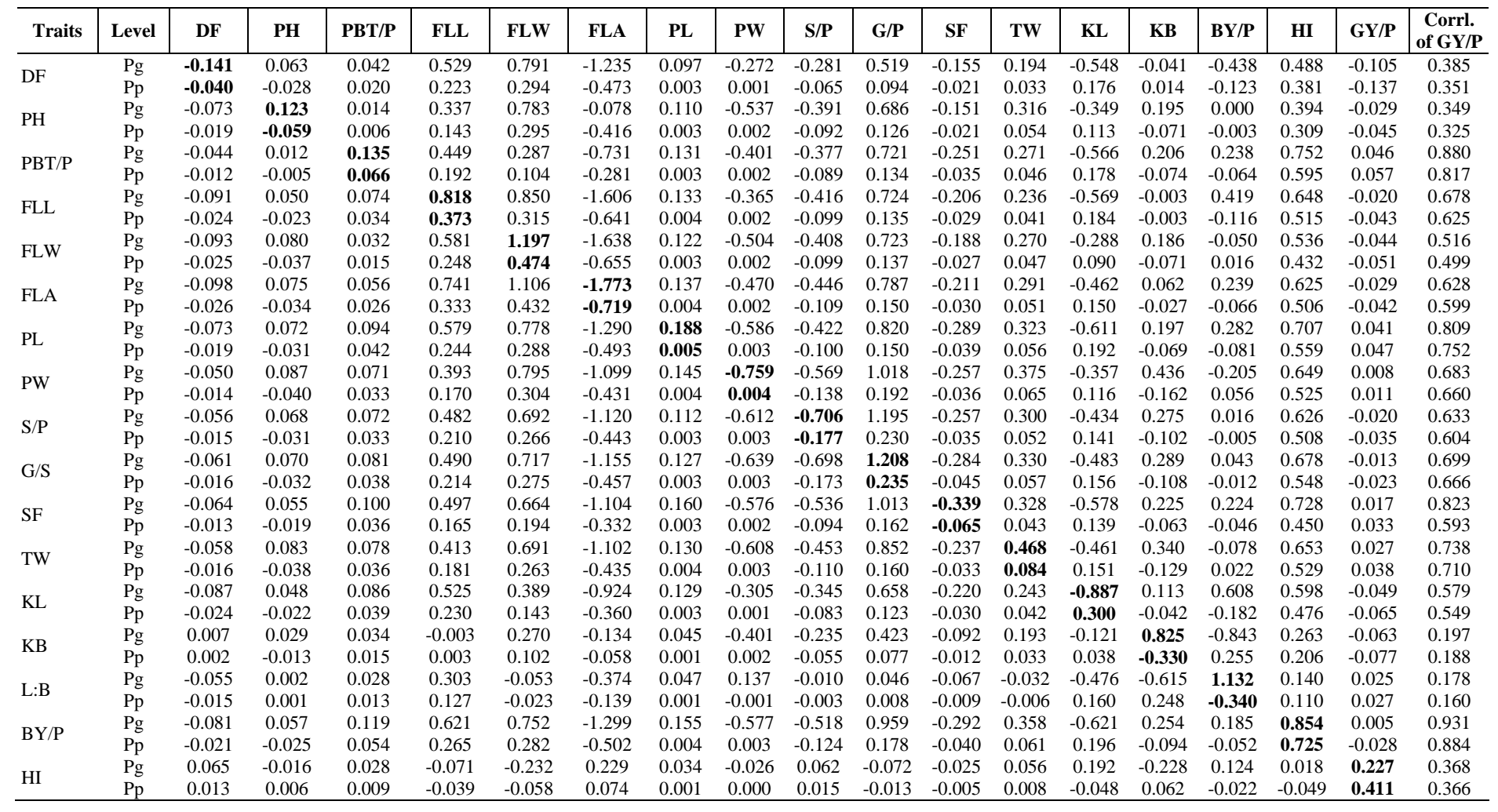

Residual factors: Genotypic $=0.0072$ and phenotypic $=0.0234$, Bold figures Indicates Indicate direct effects. Legents: $\mathrm{DF}=\mathrm{PH}=$. ...GY/P 
Table 5: Clustering pattern of 45 Indica and Tropical Japonica rice lines and their hybrids for 18 characters by Non-hierarchical Euclidean Cluster analysis

\begin{tabular}{|c|c|c|}
\hline $\begin{array}{l}\text { Cluster } \\
\text { number }\end{array}$ & $\begin{array}{c}\text { No. of } \\
\text { genotypes }\end{array}$ & Genotypes \\
\hline I & 5 & $\begin{array}{l}\text { TJ-25966, TJ-16073, TJ-25966XNDR-359, TJ-25966XCSR36, } \\
\text { TJ-25966XPB-1 }\end{array}$ \\
\hline II & 13 & $\begin{array}{l}\text { TJ-4122, TJ-16073, TJ-39050, CSR-36, TJ-4122XNDR-359, TJ- } \\
\text { 4122XCSR36, TJ-4122XPB-1, TJ1673XNDR359, } \\
\text { TJ1673XCSR36, TJ1673XPB-1, TJ-39050XNDR359, TJ- } \\
\text { 39050XCSR36, TJ-39050XPB-1 }\end{array}$ \\
\hline III & 4 & $\begin{array}{l}\text { TJ-64897, TJ-64897XNDR-359, TJ-64897XCSR36, TJ- } \\
\text { 64897XPB-1 }\end{array}$ \\
\hline IV & 4 & $\begin{array}{l}\text { TJ-10365, TJ-10365XNDR-359, TJ-10365XCSR36, TJ- } \\
\text { 10365XPB-1 }\end{array}$ \\
\hline $\mathrm{V}$ & 4 & NDR-359, Pusa Basmati-1, Pusa Basmati 1121, Sarjoo 52 \\
\hline VI & 4 & TJ-5769, TJ-5769XNDR-359, TJ-5769XCSR36, TJ-5769XPB-1 \\
\hline VII & 3 & TJ-25892XNDR359, TJ-25892XCSR36, TJ-25892XPB-1 \\
\hline VIII & 8 & $\begin{array}{l}\text { TJ-11010, TJ-16081, TJ-11010XNDR359, TJ-11010XCSR36, } \\
\text { TJ-11010XPB-1, TJ-16081XNDR-359, TJ-16081XCSR36, TJ- } \\
\text { 16081XPB-1 }\end{array}$ \\
\hline
\end{tabular}

Table 6: Average intra (Diagonal and Bold) and inter-cluster distances for18 characters in Indica and Tropical Japonica rice lines and hybrids

\begin{tabular}{|l|c|c|c|c|c|c|c|c|}
\hline Clusters & Cluster I & Cluster II & Cluster III & Cluster IV & Cluster V & Cluster VI & Cluster VII & Cluster VIII \\
\hline Cluster I & $\mathbf{1 . 8 9 2}$ & 3.375 & 4.805 & 6.506 & 5.487 & 4.930 & 5.310 & 6.695 \\
\hline Cluster II & & $\mathbf{2 . 2 0 5}$ & 3.828 & 6.840 & 4.745 & 4.351 & 6.117 & 6.980 \\
\hline Cluster III & & & $\mathbf{1 . 1 4 6}$ & 8.957 & 5.295 & 6.753 & 8.195 & 9.024 \\
\hline Cluster IV & & & & $\mathbf{1 . 1 4 0}$ & 6.751 & 4.012 & 5.471 & 3.480 \\
\hline Cluster V & & & & & $\mathbf{3 . 0 5 8}$ & 4.276 & 6.409 & 5.330 \\
\hline Cluster VI & & & & & & $\mathbf{1 . 2 8 8}$ & 5.225 & 3.881 \\
\hline Cluster VII & & & & & & & $\mathbf{1 . 3 7 8}$ & 4.602 \\
\hline Cluster VIII & & & & & & & & $\mathbf{1 . 9 9 5}$ \\
\hline
\end{tabular}


Table 7: Clusters means, standard deviation and coefficient of variation for 18 traits in Indica and Tropical Japonica rice lines and hybrids

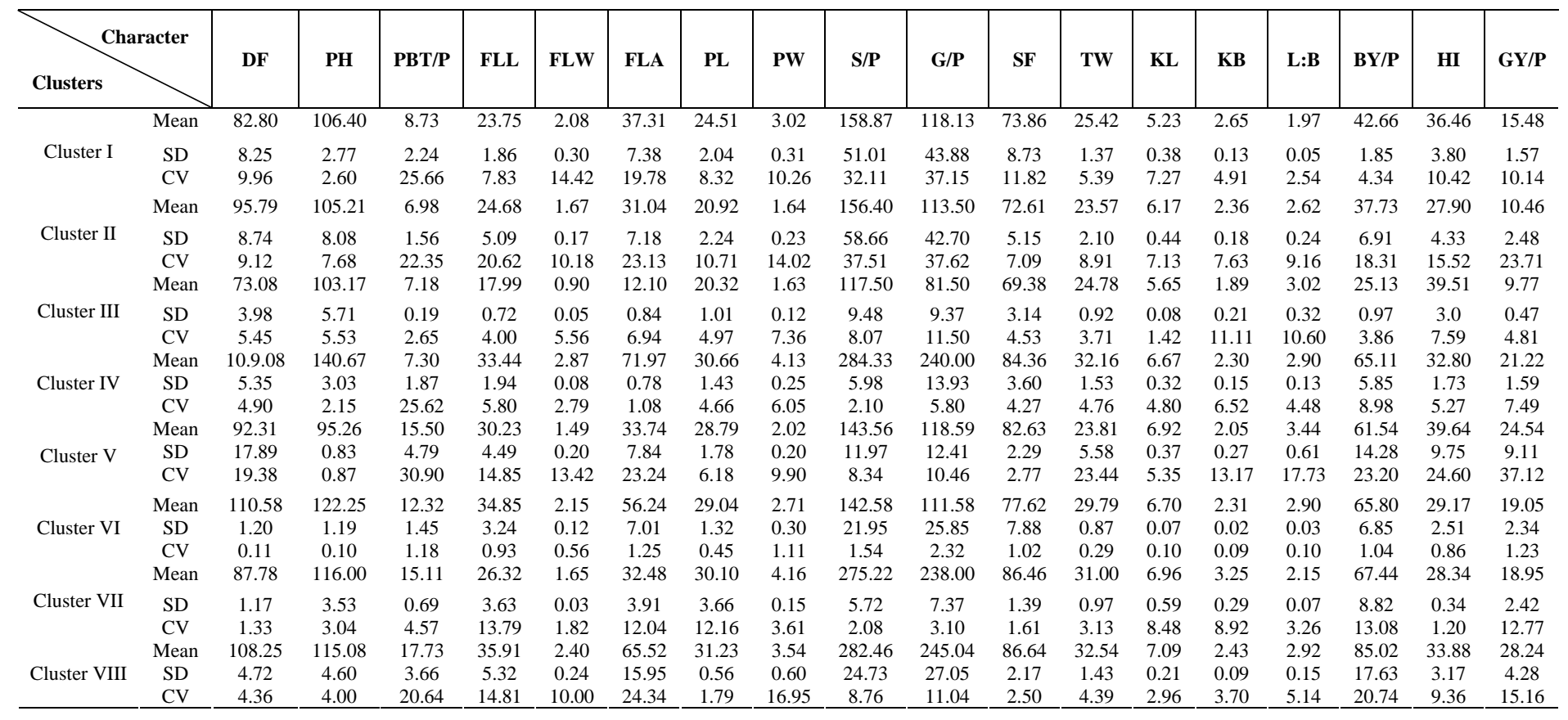


Table 8: Important superior genotypes and hybrids identified on the basis of their important traits, and cluster means in Indica and Tropical Japonica rice lines and hybrids

\begin{tabular}{|c|c|c|}
\hline Genotypes/hybrids & Cluster & Important traits \\
\hline TJ-25966 × NDR-35C & I & Short bold grain, harvest index \\
\hline TJ-25966 × CSR36 & I & Short bold grain, harvest index \\
\hline TJ-25966 × PB-1 & I & Short bold grain, harvest index \\
\hline TJ-64897 × NDR-35c & III & Fourth early days to flowering, short slender, second highest harvest i: \\
\hline TJ-64897 × CSR36 & III & Fifth early days to flowering, short slender, fifth highest harvest index \\
\hline TJ-64897 × PB-1 & III & Third early days to flowering, short slender \\
\hline TJ-10365 × NDR-35c & IV & $\begin{array}{l}\text { Third highest flag leaf width, fourth highest flag leaf area, second } 1 \\
\text { length, first highest panicle weight, third highest spikelet/ } \\
\text { grains/panicle }\end{array}$ \\
\hline TJ-10365 × PB-1 & IV & $\begin{array}{l}\text { Fourth highest flag leaf area, fifth highest panicle weight, fourth spi } \\
\text { third highest grains/panicle }\end{array}$ \\
\hline NDR-359 & $\mathrm{V}$ & Medium days to flowering, first harvest index, fourth highest grain yis \\
\hline Pusa Basmati-1 & $\mathrm{V}$ & Second dwarf plant height, long slender \\
\hline Pusa Basmati 1121 & $\mathrm{~V}$ & Fifth dwarf plant height, long slender \\
\hline Sarjoo 52 & $\mathrm{~V}$ & $\begin{array}{l}\text { Third dwarf plant height, first highest tillers/plant, third highest } \\
\text { second highest grain yield/plant }\end{array}$ \\
\hline TJ-25892 × NDR359 & VII & $\begin{array}{l}\text { First highest panicle length, third highest panicle weight, } \\
\text { spikelet/panicle, long bold slender }\end{array}$ \\
\hline TJ-25892 × PB-1 & VII & Fifth highest panicle weight, long bold slender \\
\hline TJ-11010 × NDR359 & VIII & $\begin{array}{l}\text { Second highest panicle bearing tillers/plant, second panicle weight } \\
\text { spikelets/panicle, } \\
\text { first highest grains/panicle, first highest spikelet fertility, second highı } \\
\text { long bold slender, } \\
\text { first biological yield/plant, third highest grain yield/plant }\end{array}$ \\
\hline TJ-11010 × PB-1 & VIII & $\begin{array}{l}\text { Third highest panicle bearing tillers/ plant, second highest spikelets/F } \\
\text { highest grains/panicle } \\
\text { Second highest spikelet fertility, first highest test weight, long bold } \\
\text { highest biological yield/plant, } \\
\text { first highest grain yield/plant }\end{array}$ \\
\hline TJ-16081× NDR-359 & VIII & $\begin{array}{l}\text { Fourth panicle bearing tillers/plant, first flag leaf length, fourth flas } \\
\text { fifth highest grains/ panicle, } \\
\text { third highest test weight, long slender, second highest biological yi } \\
\text { highest grain yield/plant }\end{array}$ \\
\hline TJ-16081× PB-1 & VIII & $\begin{array}{l}\text { Fifth highest panicle bearing tillers/plant, second flag leaf length, fir } \\
\text { leaf area, fourth highest } \\
\text { panicle length, fifth highest test weight, long slender, fifth biological s }\end{array}$ \\
\hline
\end{tabular}

